\title{
E-Prescription: Connecting Patients' Prescriptions with Pharmacists and Cashiers
}

\author{
Helfy Susilawati $^{{ }^{*}}$, Tri Arif Wiharso ${ }^{2}$ \\ ${ }^{1}$ Electrical Engineering \\ Universitas Garut \\ Garut, Indonesia \\ ${ }^{2}$ Telecommunications Engineering \\ Universitas Garut \\ Garut, Indonesia \\ *helfy.susilawati@uniga.ac.id
}

\begin{abstract}
The paper describes the development of an electronic prescription system. Electronic prescription or e-prescription is an innovation in the health sector that enables patients to read the types of medication they will receive along with its description and rational use. E-prescription shortens the waiting time to get a prescription, which is different from a manual prescription system. In conventional systems, patients must undergo several steps to get served. They have to give the prescriptions to the cashier and wait for the cashier to calculate the bill. They later submit the proof of payment to the pharmacists and wait for the pharmacist to produce the medicine. Using e-prescription, the patients only have to pay for prescription and wait for the pharmacists to bring the medicine. The waiting time may decrease from 4 complicated steps into 2 simple ones. The website-based e-prescription application enables physicians to electronically send prescriptions to pharmacy computers and send its bill to the cashier. The system allows patients to directly move to the pharmacy once they have paid the bill. The research adopts a quantitative method with a prototype research model and UAT (User Acceptance Test) model for testing.
\end{abstract}

Keyword: e-prescription, prototype, pharmacy, user acceptance test

Article info: submitted September 24, 2020, revised November 2, 2020, accepted December 1, 2020

\section{Introduction}

Electronic prescription is a type of health information technology that allows prescribers to send electronic prescriptions safely to the intermediary (i.e. pharmacists) by using a software [1]information technologies also may introduce different kinds of medication errors. Objective: To identify and quantify e-prescribing problems reported through an electronic prescribing incident reporting tool in the United States. Methods: Voluntary and anonymous reports to a web-based, e-prescribing incident reporting tool were collected during 18 months using convenience sampling. Questions in the reporting tool were designed to elicit information on pharmacists' experiences with e-prescribing. Data were analyzed to characterize the different types of e-prescribing concerns. Results: A total of 484 reports were collected through the incident reporting tool. Out of 484 reports, $75 \%$ corresponded to electronic prescriptions received directly into pharmacies' computers and $23 \%$ were computer- generated prescriptions faxed to pharmacies. Most of reports corresponded to comments, complaints or identified unsafe conditions regarding electronic prescriptions $(49 \%$. The electronic prescribing system is a series of prescribing processes that use software in order to simplify drug prescribing services [2]. According to the Regulation of the Minister of Health of the Republic of Indonesia, this electronic prescription system does not go against any existing laws in Indonesia [3] Emerald Publishing Limited. Purpose: This paper examines the influence of three dimensions of customer knowledge management - knowledge from customer, knowledge for customer and knowledge about customer - on innovation capabilities (speed and quality. The purpose of developing e-prescription is to reduce errors in the drug administration process and also to simplify the pharmacists's services. E-prescription can provide many benefits including time and cost savings for all parties involved[4]. It is evident in the fact that of the 25 studies conducted, 23 studies indicated the effectiveness of e-prescription in reducing the errors in drug treatment 
from $13 \%$ to almost $99 \%$ [5]. E-prescription which is a web-based application has a very important role because it displays an element of the intangibility of the service itself [6]. According to a research in [7], hospital websites, despite some differences in some countries, usually function more as a place to store information and display traditional contact details. However, e-prescription can join the existing hospital website which enables the hospitals or health centers having a new unit in one application. This study aims connects the patients' prescription which is prescribed by doctors with the cashiers and pharmacists.

In some countries, research on e-prescription has been conducted extensively. However, those research emphasizes on the effectiveness of e-prescription rather than the development of the system. Meanwhile, in Indonesia, research on e-prescription is still focusing on developing an information system i.e., e-prescription to support administrative works. One of the studies that investigated the use of e-prescription and the factors influencing it have been conducted in Dr. Wahidin Sudirohusodo's clinic in Makassar. In that study, the e-prescription was partially applied in the hospital and the parts of the e-prescription were also fragmented [8]. In our study, we aim to build a web-based application system that may help the development of the e-prescription system which starts to develop.

\section{Method}

\section{a. Related Works}

Research that evaluate the effetiveness of e-prescription have been widely carried out in other countries. For instance, a study conducted by Amber Porterfield et al. found that e-prescription can improve the efficiency and accuracy of prescribing for patients. The results of the study suggest that electronic prescribing has the potential to improve adherence, save costs for medication, hospitals and patients, as well as increase the service efficiency for the patients [9]. Another study conducted by Yogini Hariprasad Jan et al, showed that manual prescription system had an average error of $77.4 \%$, while e-presription only resulted in $4.8 \%$ average errors. Before the existence of e-prescription, there were 1153 items losing important information, whereas after using the e-prescription, there were only 9 items missing important information [10].

In Indonesia, most stakeholders (prescribers or physicians) use manual systems in which patients will be manually given hand-written prescriptions by the prescribers and asked to send them to the cashiers and pharmacies. Then, after giving the prescriptions to the cashiers, the patients will be asked to wait for the cashiers to calculate the amount of money that the patients need to pay for the medicine and they can make some payment. After paying the cost, the patients are requested to wait for the prescription and wait for the pharmacists to prepare the medicine. Therefore, we argue that if the stakeholders use electronic prescription, the process will be much simpler where the physicians can directly connect to the cashiers and pharmacists, while the patients just need to wait for the patient's queue number to be called and then immediately pay for the medicine. Then, the pharmacy will be immediately handling the medicine that has been previously paid. One of the studies related to e-prescription has been conducted by Puspa Setia Pratiwi and Andri Lestari. The study investigated the implementation of a clinical pharmacy prescription system. The results showed that the the clinic has developed an e-prescribing system [11]. The difference between the existing research and our study is that in our study we develop an information system with an additional feature that not only connect patients' prescriptions with the pharmacists but also with the cashiers.

Another research on the e-prescription was the one conducted by Juwita et al. The study which was conducted at Dr. Wahidin Sudirohusodo's clinical center in Makassar analyzed the implementation of the e-prescription and the factors influencing it. The results indicated that the human resources as the executors were sufficient. However, computer facilities to apply the electronic prescription and other supporting applications were insufficient causing the need for further improvement. Moreover, there were also other important works to be done such as developing the application of Electronic Drug Control ( E-KPO), Electronic Medical Record (E-KPO) and Clinical Decision Support System, making connection to the clinical support results, giving education on how to run the application in the cell phones instead of computers, conducting direct monitoring throughout the room, and eliminating manual prescription sheets.

The results of the study imply that currently the electronic prescription has started to be applied. However, it is only used partially since there were still manual prescription sheets being used and the electronic prescription was still separated in from one unit to another[8]. The present study intends to fill the gaps by investigating the connections of the patients' prescriptions with not only the the pharmacy but also the cashiers so that the relationship between different units can be determined.

\section{b. Method}

To achieve the objective, the study utilized a quantitative method with a prototype research model and UAT (User Acceptance Test) as the testing system. The prototype method is a method in which a model of the software can be released first by involving several users who will generate feedback for further improvements [12]. According to Roger S Pressman, designing a system to be developed can use the prototype method. The prototype method is suitable for developing a system that will be reestablished. The 
prototype is not a final product, but it is something that must be re-evaluated and modified. Any changes can occur when the prototype is made to meet the needs of the users which at the same time may help the developers understand the users' needs better [13].

The user acceptance test is usually used by clients and/or end users to identify what system can do [14]. The aim of the user acceptance test is to figure out whether or not the customers' needs have been fulfilled by the system [15]. User acceptance test is performed by the clients to find out the limitation of the software system [16]. It is also used by the users to produce documents to be used as evidence that the developed application can be accepted by the user [17]. From those claims, it can be concluded that the user acceptance test is a test used by the clients to determine the respondent's satisfaction towards the software being made.

\section{Results}

\section{a. Electronic Prescription Flow}

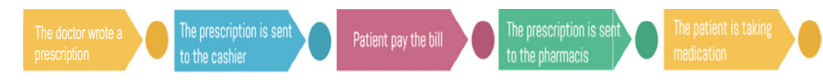

Figure 1. Electronic Prescription Flow

Figure 1 shows the flow of electronic prescribing. In the first stage, the doctor writes a prescription for the patient, and the written prescription recorded on the website will then be electronically sent to the cashier. Meanwhile, the printout of the prescription will be given to the patient as he/she has the rights to know what drug prescription he receives. After receiving the printout, the patient will have to go to the cashiers to pay for the medicine. The patient will be given a queue number and the pharmacy will give the medicine after the patient's queue number is called. When the patient takes the medicine, the printed out prescription that has been given by the doctor is submitted to the pharmacist in order to prevent a misuse of prescriptions by patients.

\section{b. Result}

To obtain a valid data, the researchers conducted the interviews with doctors, cashiers, and pharmacists at a health center / clinic. Based on the data, an electronic prescription has been established in accordance with the prescription standards that should be given by the doctor. The prescribing process encloses the information about the name of the patient, the patient's address, the name of the doctor, the date of the examination and the administration of the drug. Moreover, it also covers the information on the type of drug, the form of the drug, the dosage of the drug, and the procedure for taking the drug.

The following is a database design for the application.

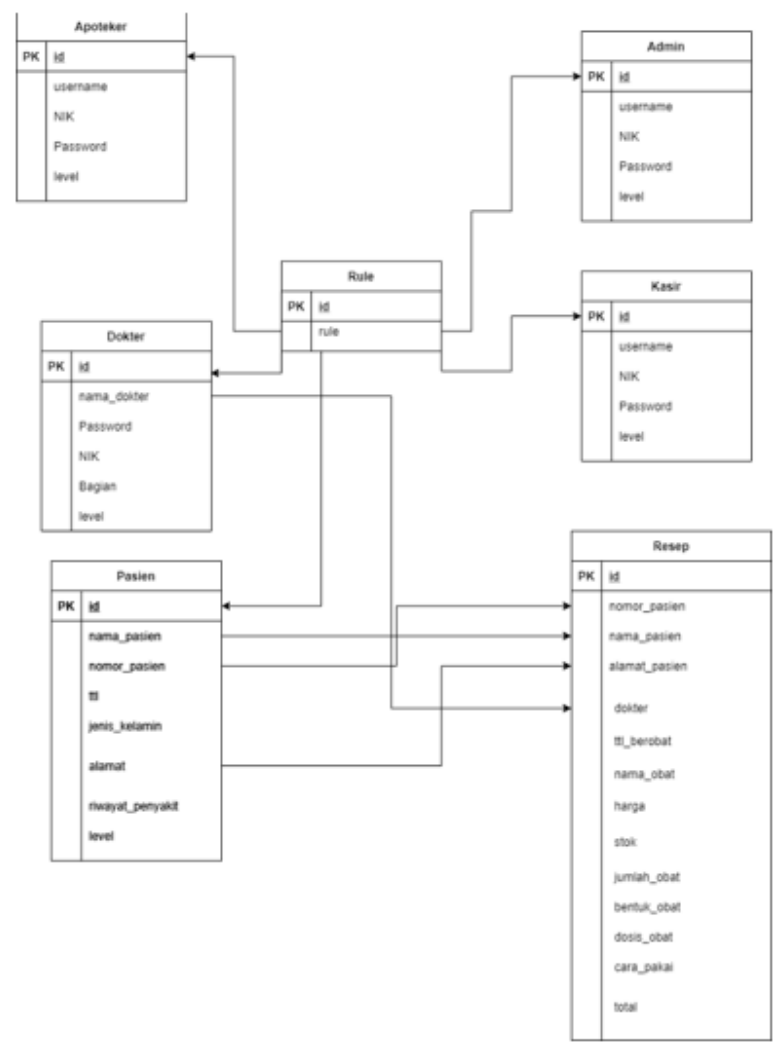

Figure 2. Database

Figure 2 shows database design from the application. The following is an overview of the created application.

Selamat Datang Dokter Malika

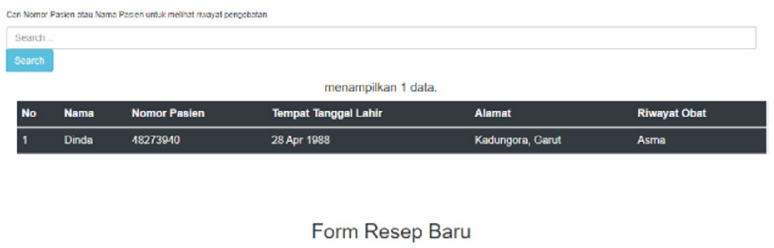

Figure 3. Doctor Page

Figure 3 indicates the doctor page. On this page, the doctor can see the patient's personal information such as the patient's number, name, address, date of birth and medical record. This is provided to enable the doctor to check if there are errors in the patient's personal information, and to find out the patient's drug history to avoid any errors in prescribing the drugs.

Figure 4 shows the prescription page. In this page, the doctor needs to enter the patient's number or name, so that the patient's data will be automatically filled in. The doctor then types his/her name, the date of the examination and the drugs given. When it comes to the drug, the doctor should provide information about the number of drugs in each item, the form of the drug, the dosage of the drug and the number of times it should be taken. In this page, as the doctor selects or searches for a drug, the doctor will know the availability of the drug and its price since such information is filled in automatically 


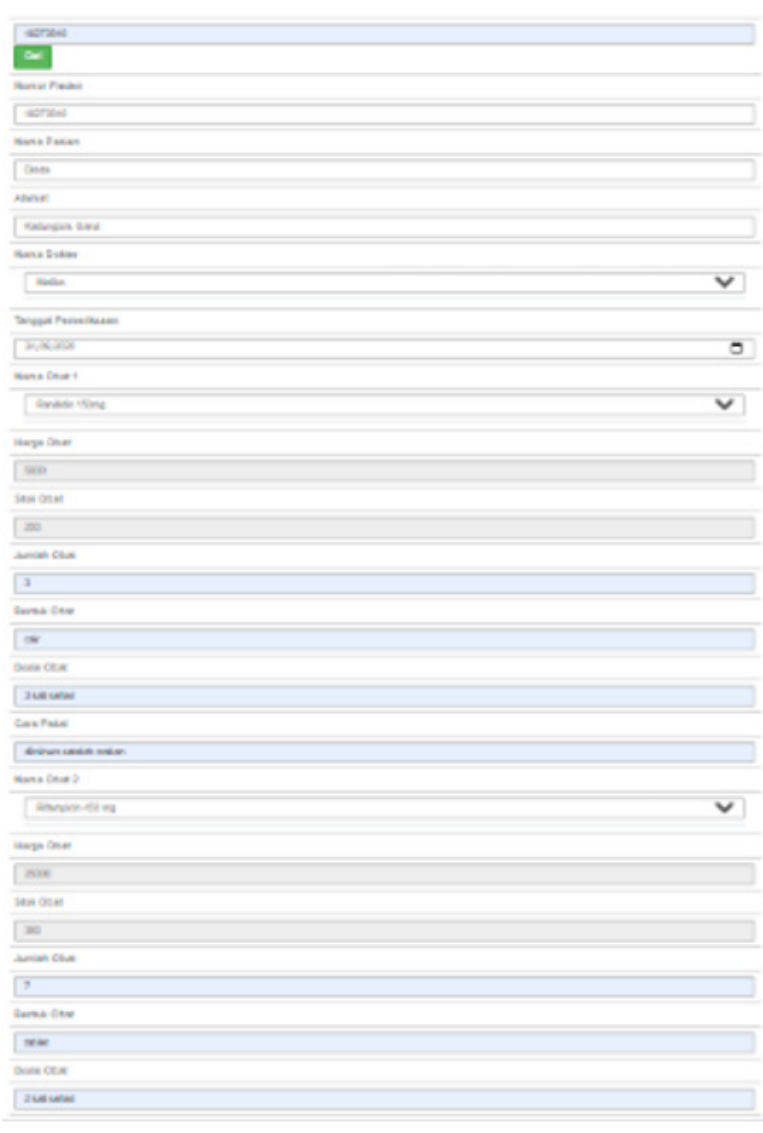

Figure 4. Prescription Page

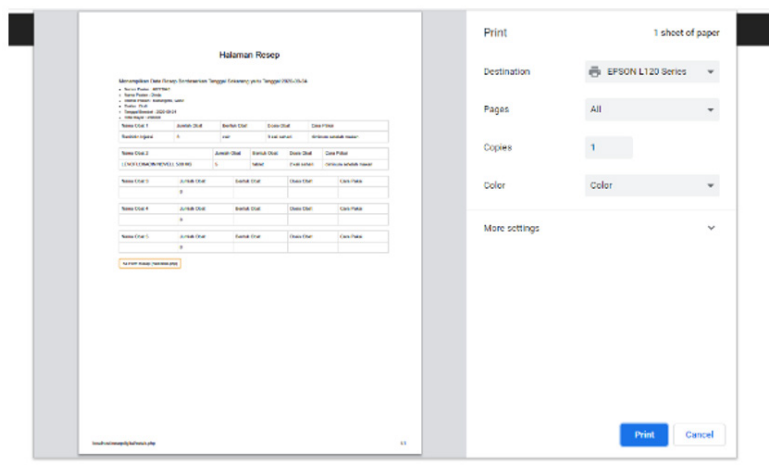

Figure 5. Prescription Print Page

Figure 5 shows a print page of the prescription. In this page, the doctor can print out the the prescription that will be given to the patient. It is important to note that when entering this page, the prescription made by the doctor will directly go to the cashier's page..

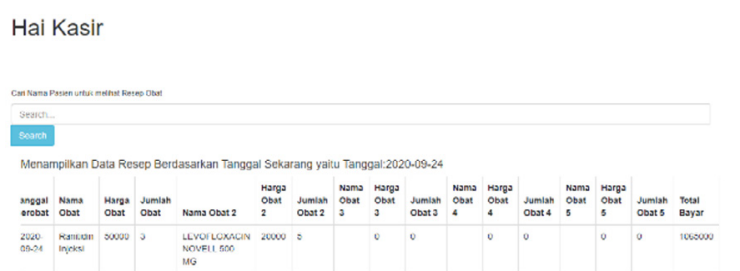

Figure 6. Cashier Page
Figure 6 displays the cashier page. In this page, the information about the patient's name, number and address, the doctor, the date of the treatment, the name, the price and the amount of the medicine, and the total that must be paid by the patient is show. This is done so that the cashier can make confirmation on the patient's information and calculate the amount of money that the patient has to pay.

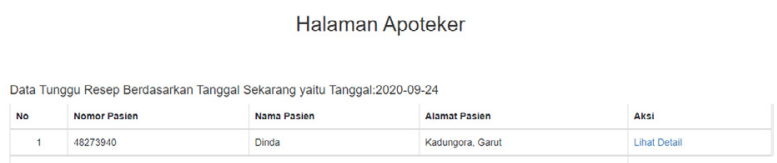

Figure 7. Pharmacist Page

Figure 7 is the example of the pharmacist page. The pharmacist page shows a list of prescription made that day only. In other words, the previous data will not be displayed. On the action tab, the pharmacist can see the detail description of the drug that the patient needs.

Halaman Detail Resep

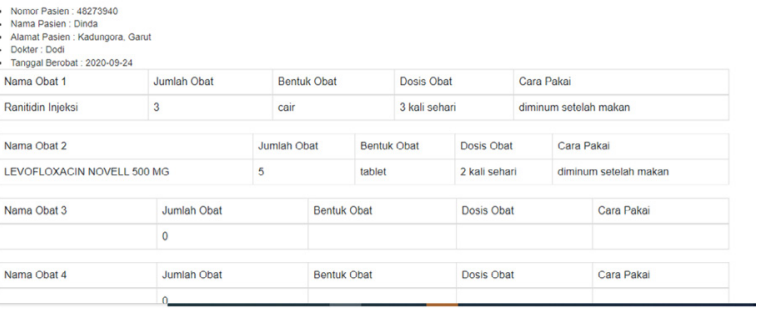

Figure 8. Detail Prescription Page

Figure 8 displays the details of the patient's prescription. This page shows the detail information about the prescription given by the doctor. The only thing that does not appear on this page is the price and total payment that the patients should make because such things will be handled by the cashier.

To protect the website from the external attacks, a security was installed on the website. The security applications installed are SSL (Secure Socket Layer) and Cloudflare. SSL serves to protect the website by encrypting the data so that the outsiders will gain no access. Meanwhile, Cloudflare serves to monitor malicious actions on the website. It helps filter and block the actions that are perceived to be dangerous

To test the functionalaity of the application, the Black Box Testing method was used. This black box testing was given to 30 respondents.

Table 1 indicates the results of the Black Box Testing. Based on the results, it can be concluded that all features are running well.

The instrument used for UAT testing was a questionnaire. The questionnaire given was in the form of 1 to 5 Likert scales with 1 as strongly disagree and 5 as strongly agree. The Likert scale was used because it is intended to measure the respondents' attitudes, opinions, 
and perceptions. In this scale, the measured variable is first translated into some indicators which then serve as a starting point for arranging the instrument items which are in form of statements or questions [18].

Table 1. Black Box Testing

\begin{tabular}{|c|c|c|c|c|}
\hline No & Case & $\begin{array}{c}\text { Test } \\
\text { Scenarios }\end{array}$ & $\begin{array}{l}\text { Expected } \\
\text { results }\end{array}$ & $\begin{array}{c}\text { Test } \\
\text { result }\end{array}$ \\
\hline 1 & Login Page & $\begin{array}{l}\text { Users with } \\
\text { various roles, } \\
\text { for example, } \\
\text { doctor or } \\
\text { cashier log } \\
\text { in and are } \\
\text { directed } \\
\text { to their } \\
\text { respective } \\
\text { pages. }\end{array}$ & $\begin{array}{l}\text { When the } \\
\text { doctor enters } \\
\text { the doctor user } \\
\text { and clicks the } \\
\text { login button, } \\
\text { the doctor will } \\
\text { be directed } \\
\text { to the doctor } \\
\text { page. When } \\
\text { the cashier logs } \\
\text { in, the cashier } \\
\text { is directed to } \\
\text { the cashier } \\
\text { page. }\end{array}$ & $\nabla$ Good \\
\hline 2 & $\begin{array}{l}\text { Drug } \\
\text { History }\end{array}$ & $\begin{array}{l}\text { On the } \\
\text { doctor's } \\
\text { page, there } \\
\text { is a button } \\
\text { to search for } \\
\text { the patient's } \\
\text { name and to } \\
\text { view patients' } \\
\text { drug history. }\end{array}$ & $\begin{array}{l}\text { When the } \\
\text { doctor types } \\
\text { the patient's } \\
\text { name or } \\
\text { patient's } \\
\text { number in the } \\
\text { search button, } \\
\text { the page will } \\
\text { immediately } \\
\text { display } \\
\text { detailed } \\
\text { data about } \\
\text { the patient } \\
\text { including the } \\
\text { patient's drug } \\
\text { history. }\end{array}$ & $\square$ Good \\
\hline 3 & $\begin{array}{l}\text { Creating } \\
\text { a new } \\
\text { prescription }\end{array}$ & $\begin{array}{l}\text { On this } \\
\text { page, the } \\
\text { doctor can } \\
\text { create new } \\
\text { prescriptions } \\
\text { for the } \\
\text { patients. }\end{array}$ & $\begin{array}{l}\text { The } \\
\text { prescription } \\
\text { form functions } \\
\text { well in which } \\
\text { the doctor } \\
\text { can fill in the } \\
\text { necessary data } \\
\text { regarding } \\
\text { the drug } \\
\text { description. } \\
\text { Meanwhile, } \\
\text { regarding } \\
\text { the name of } \\
\text { the drug, the } \\
\text { doctor can } \\
\text { immediately } \\
\text { search for } \\
\text { it with the } \\
\text { dropdown } \\
\text { features. }\end{array}$ & $\nabla$ Good \\
\hline
\end{tabular}

\begin{tabular}{|c|c|c|c|c|}
\hline No & Case & $\begin{array}{c}\text { Test } \\
\text { Scenarios }\end{array}$ & $\begin{array}{c}\text { Expected } \\
\text { results }\end{array}$ & $\begin{array}{c}\text { Test } \\
\text { result }\end{array}$ \\
\hline 4 & $\begin{array}{l}\text { Prescription } \\
\text { can be } \\
\text { printed }\end{array}$ & $\begin{array}{l}\text { The } \\
\text { prescription } \\
\text { given by the } \\
\text { doctor can be } \\
\text { printed and } \\
\text { given to the } \\
\text { patients }\end{array}$ & $\begin{array}{l}\text { Patients can } \\
\text { receive a } \\
\text { printout of the } \\
\text { prescription } \\
\text { given by the } \\
\text { doctor }\end{array}$ & $\square$ Good \\
\hline 5 & $\begin{array}{l}\text { Data can } \\
\text { be seen on } \\
\text { the cashier } \\
\text { page }\end{array}$ & $\begin{array}{l}\text { After the } \\
\text { doctor fills } \\
\text { in the drug } \\
\text { prescription } \\
\text { form for the } \\
\text { patient, the } \\
\text { data can be } \\
\text { seen on the } \\
\text { cashier page. }\end{array}$ & $\begin{array}{l}\text { On the } \\
\text { cashier page, } \\
\text { the doctor's } \\
\text { prescription } \\
\text { can be seen } \\
\text { along with the } \\
\text { total payment } \\
\text { that has been } \\
\text { calculated on } \\
\text { the cashier } \\
\text { page. }\end{array}$ & $\square$ Good \\
\hline 6 & $\begin{array}{l}\text { Drug data } \\
\text { can be seen } \\
\text { on the } \\
\text { pharmacist } \\
\text { page }\end{array}$ & $\begin{array}{l}\text { Pharmacists } \\
\text { see drug data } \\
\text { required by } \\
\text { the patient }\end{array}$ & $\begin{array}{l}\text { The detail } \\
\text { information } \\
\text { about the } \\
\text { prescription } \\
\text { from the } \\
\text { doctor can be } \\
\text { seen by the } \\
\text { pharmacists. }\end{array}$ & $\nabla$ Good \\
\hline
\end{tabular}

Table 2. Likert Scale

\begin{tabular}{|l|l|l|}
\hline \multirow{2}{*}{ Statement } & \multicolumn{2}{c|}{ Answer (Score) } \\
\cline { 2 - 3 } & \multicolumn{1}{|c|}{ Positive (+) } & \multicolumn{1}{c|}{ Negative (-) } \\
\hline Strongly Agree / Always / Very Appropriate & 5 & 1 \\
\hline Agree / Often / Appropriate & 4 & 2 \\
\hline Uncertain / Occasionally / Neutral & 3 & 3 \\
\hline Disagree / Almost never / No corresponding & 2 & 4 \\
\hline $\begin{array}{l}\text { Strongly disagree / Never / Strongly it is not } \\
\text { in accordance }\end{array}$ & 1 & 5 \\
\hline
\end{tabular}

The performance of the developed web-based application was tested by using gtmetrix.

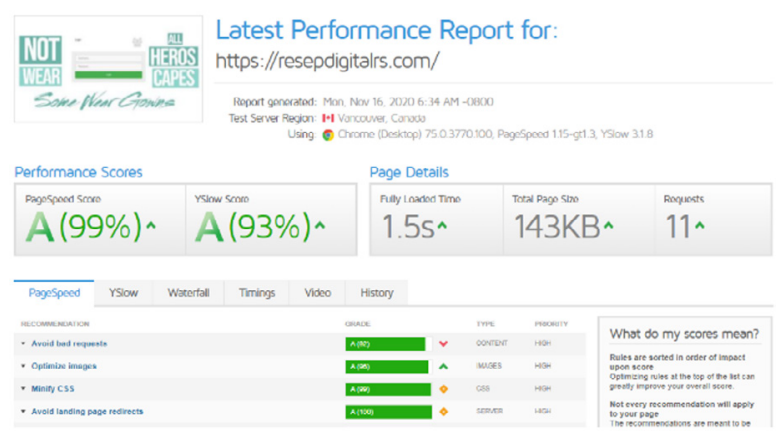

Figure 9. Result of the website performance 
Figure 9 shows the result of the website performance. Website has 99\% to page speed score, 93\% for Ylow score, and fully loaded time 1,5 second.

\section{Discussion}

To obtain the data regarding the use of the system, several questions were formulated.

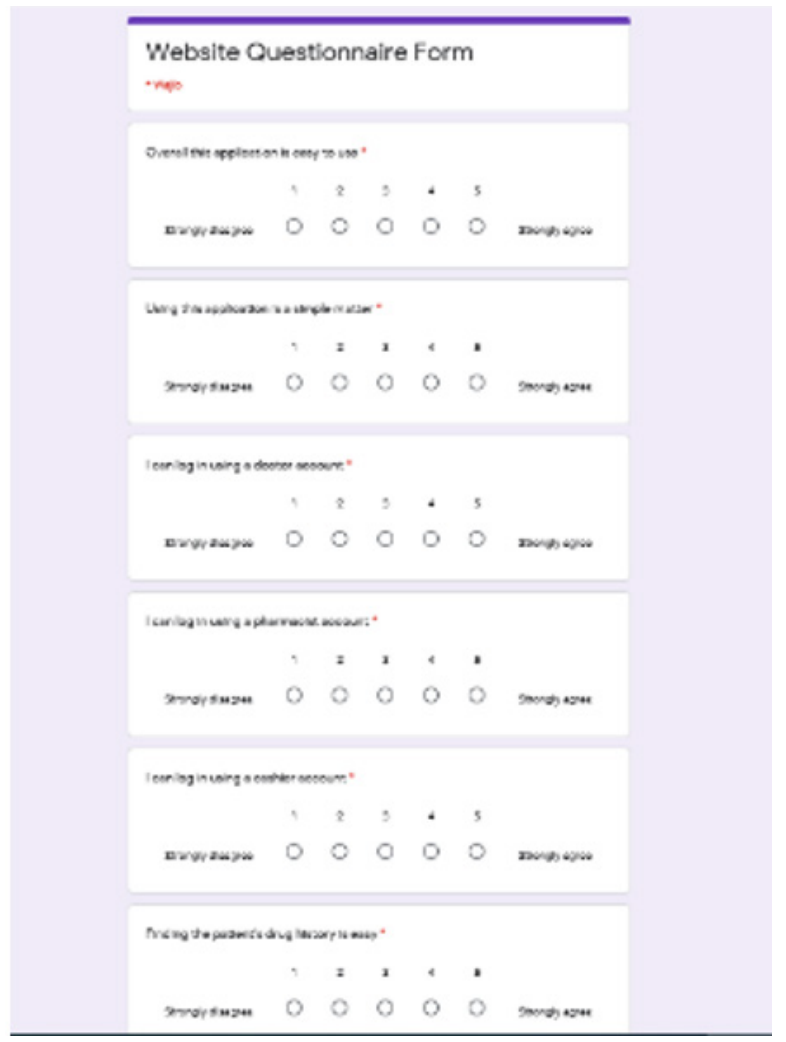

Figure 10. Questionnaire Form

Figure 10 shows the questionnaire administred to the respondents to get the desired data. The questionnaire consists of 12 questions or statements which can be seen in Table 3.

Table 3. Questions or Statements in the questionnaire

\begin{tabular}{cl}
\hline Number & \multicolumn{1}{c}{ Question or Statement } \\
\hline Q1 & Overall this application is easy to use \\
Q2 & Using this application is very simple \\
Q3 & I can log in using a doctor account \\
Q4 & I can log in using a pharmacist account \\
Q5 & I can log in using a cashier account \\
Q6 & Finding the patients drug histories is easy \\
Q7 & Creating new prescriptions for the patients is easy \\
Q8 & Printing a doctor's prescription is easy \\
Q9 & Viewing the list of patients who have to pay is easy \\
Q10 & It is easy to see how much a patient has to pay \\
Q11 & Viewing the list of patients who need to prepare the \\
& drugs is easy \\
Q12 & Viewing the prescription along with its detail \\
& descriptions is easy \\
\end{tabular}

Table 3 outlines the questions or statements given to the respondents. The number of statements or questions given is 12 . The results of the questionnaire given to 30 respondents can be seen in Table 4 .

Table 4. Respondent's Responses

\begin{tabular}{cccccc}
\hline \multicolumn{6}{c}{ Respondent's Responses } \\
\hline Question & $\begin{array}{c}\text { Strongly } \\
\text { Agree (5) }\end{array}$ & $\begin{array}{c}\text { Agree } \\
\mathbf{( 4 )}\end{array}$ & $\begin{array}{c}\text { Uncertain } \\
\mathbf{( 3 )}\end{array}$ & $\begin{array}{c}\text { Disagree } \\
\mathbf{( 2 )}\end{array}$ & $\begin{array}{c}\text { Strongly } \\
\text { disagree } \\
(\mathbf{1})\end{array}$ \\
\hline Q1 & 15 & 6 & 9 & 1 & 0 \\
Q2 & 15 & 10 & 4 & 1 & 0 \\
Q3 & 15 & 3 & 10 & 1 & 2 \\
Q4 & 15 & 5 & 8 & 1 & 2 \\
Q5 & 11 & 6 & 10 & 1 & 3 \\
Q6 & 13 & 6 & 10 & 1 & 1 \\
Q7 & 10 & 9 & 8 & 3 & 1 \\
Q8 & 12 & 8 & 9 & 1 & 1 \\
Q9 & 12 & 6 & 11 & 0 & 2 \\
Q10 & 13 & 8 & 8 & 0 & 2 \\
Q11 & 9 & 13 & 8 & 0 & 1 \\
Q12 & 15 & 6 & 7 & 2 & 1 \\
Sum & 155 & 86 & 102 & 12 & 16 \\
\hline
\end{tabular}

Table 4 covers the results of the questionnaire. The number of respondents who chose to give score 5 was 775 , the number of respondents who chose to give score 4 was 344 , the number of respondents who chose to give score 3 was 306 the number of respondents who chose to give score 2 was 24 and the number of respondents who chose to give score 1 was 16 . The total score was 1465 .

The highest score was $30^{*} 12^{*} 5=1800$, and the lowest score was $30^{*} 12^{*} 1=360$. The percentage of the results was $1465 / 1800^{*} 100 \%=81,39 \%$. Classifications for usability have 5 classification. First, $0 \%-20 \%$ is very weak, $21 \%-40 \%$ is weak, $41 \%-60 \%$ is enough, $61 \%-80 \%$ is strong, $81 \%-100 \%$ is very strong. Based on the results, it can be inferred that the level of the website application system usability is very strong.

Although there were positive results, some improvement on some parts still need to be made. There is a limitation on the part of the cashier payment system which is yet connected to the bank. Therefore, it will be beneficial to collaborate with the bank which may enable the prescription payment to be done online through mobile or internet banking. In addition to the payment system, the security of the website also needs to be improved so that it will not be depended on the third parties for its security.

\section{Conclusion}

Based on the result, it can be said that the applications that have been built runs quite well. It is evident in the fact that the prescription given by the doctor can be electronically sent to the cashier and pharmacist and be printed out for the patients. This causes the patient's waiting time to be shorter. For further development, 
the pharmacy can collaborate with the bank to make the payment process easier. By this way, the patients can pay for the prescribed drugs through mobile or internet banking which may help shorten the waiting time of the patients to get the medicine.

\section{Acknowledgement}

We thank the doctors, the cashiers and the pharmacists at the Health Center for their willingness to provide information about the prescribing and payment procedures. We also thank Ristekdikti for providing PDP research funding.

\section{Bibliography}

[1] A. L. Hincapie, T. Warholak, A. Altyar, R. Snead, and T. Modisett, "Electronic prescribing problems reported tothePharmacy and Provider ePrescribing Experience Reporting (PEER) portal,” Res. Soc. Adm. Pharm., vol. 10, no. 4, pp. 647-655, 2014, doi: 10.1016/j.sapharm.2013.08.007.

[2] F. C. Sabila et al., "Peresepan Elektronik ( E-Prescribing ) Dalam Menurunkan Kesalahan Penulisan Resep Elecronical Prescribing ( E-Prescribing ) to Reduce Prescribing Error," Med. J. Lampung Univ., vol. 7, no. 3, pp. 271-275, 2018, [Online]. Available: http://juke.kedokteran. unila.ac.id/index.php/majority/article/view/2090.

[3] Permenkes, Peraturan Menteri Kesehatan Republik Indonesia No 73 Tentang Standar Pelayanan Kefarmasian di Apotek. 2016.

[4] A. Porterfield, K. Engelbert, and A. Coustasse, "Electronic prescribing: improving the efficiency and accuracy of prescribing in the ambulatory care setting," Perspect. Health Inf. Manag., 2014.

[5] E. Ammenwerth, P. Schnell-Inderst, C. Machan, and U. Siebert, "The Effect of Electronic Prescribing on Medication Errors and Adverse Drug Events: A Systematic Review," J. Am. Med. Informatics Assoc., 2008, doi: 10.1197/jamia. M2667.

[6] L. Hakim and L. Deswindi, "Assessing the Effects of e-servicescape on Customer Intention: A Study on the Hospital Websites in South Jakarta," Procedia - Soc. Behav. Sci., vol. 169, no. August 2014, pp. 227-239, 2015, doi: 10.1016/j. sbspro.2015.01.306.

[7] M. P. Bach, S. Seljan, B. Jaković, A. Buljan, and J. Zoroja, "Hospital Websites: From the Information Repository to Interactive Channel," 2019, doi: 10.1016/j.procs.2019.12.155.

[8] Juwita, F. Rivai, and Ansariadi, "Qualitative study on implementation of electronic recipes (E-recipes) in Dr. Wahidin Sudirohusodo Hospital, Makassar," Enferm. Clin., 2020, doi: 10.1016/j.enfcli.2019.10.085.

[9] A. Porterfield, K. Engelbert, and A. Coustasse, "Electronic prescribing: improving the efficiency and accuracy of prescribing in the ambulatory care setting," Perspect. Health Inf. Manag., vol. 11, no. May 2014, 2014.

[10] Y. H. Jani, M. A. Ghaleb, S. D. Marks, J. Cope, N. Barber, and I. C. K. Wong, "Electronic Prescribing Reduced Prescribing Errors in a Pediatric Renal Outpatient Clinic,” J. Pediatr., 2008, doi: 10.1016/j.jpeds.2007.09.046.

[11] P. S. Pratiwi and A. Lestari, "E-Prescribing : Studi Kasus Perancangan dan Implementasi Sistem Resep Obat Apotik Klinik E-Prescribing: Studi Kasus Perancangan dan Implementasi," vol. 10, no. December 2013, pp. 9-14, 2016.

[12] R. Ganpatrao Sabale, "Comparative Study of Prototype Model For Software Engineering With System Development Life Cycle," IOSR J. Eng., 2012, doi: 10.9790/3021-02722124.

[13] R. S. Pressman, "Rekayasa perangkat lunak: pendekatan praktisi," Komput. - PERANGKAT LUNAK, Andi Publ., 2002.

[14] C. K. N. C. K. Mohd and F. Shahbodin, "Personalized Learning Environment: Alpha Testing, Beta Testing \& User Acceptance Test," Procedia - Soc. Behav. Sci., vol. 195, pp. 837-843, 2015, doi: 10.1016/j.sbspro.2015.06.319.

[15] I. Otaduy and O. Diaz, "User acceptance testing for Agile-developed web-based applications: Empowering customers through wikis and mind maps," J. Syst. Softw., vol. 133, pp. 212-229, 2017, doi: 10.1016/j.jss.2017.01.002.

[16] D. Tte and D. A. N. Barcode, "USER ACCEPTANCE TEST ( UAT ) SISTEM BARU ASROT," 2019.

[17] A. B. Mutiara, A. Rifky, A. Muslim, and O. Teddy, "Testing Implementasi Website Rekam Medis Elektronik Opeltgunasys Dengan Metode Acceptance ...," Semin. Ilm. Nas. Komput. dan Sist. Intelijen (KOMMIT 2014), 2014.

[18] Sugiyono, "Sugiyono, Metode Penelitian dan Pengembangan Pendekatan Kualitatif, Kuantitatif, dan R\&D , (Bandung: Alfabeta, 2015), 407 1," Metod. Penelit. dan Pengemb. Pendekatan Kualitatif, Kuantitatif, dan R\&D, 2015. 